\title{
Researchers shocked at UK's plan to exit EU nuclear agency
}

The United Kingdom's role in major fusion projects remains in limbo.

\section{Elizabeth Gibney}

27 January 2017

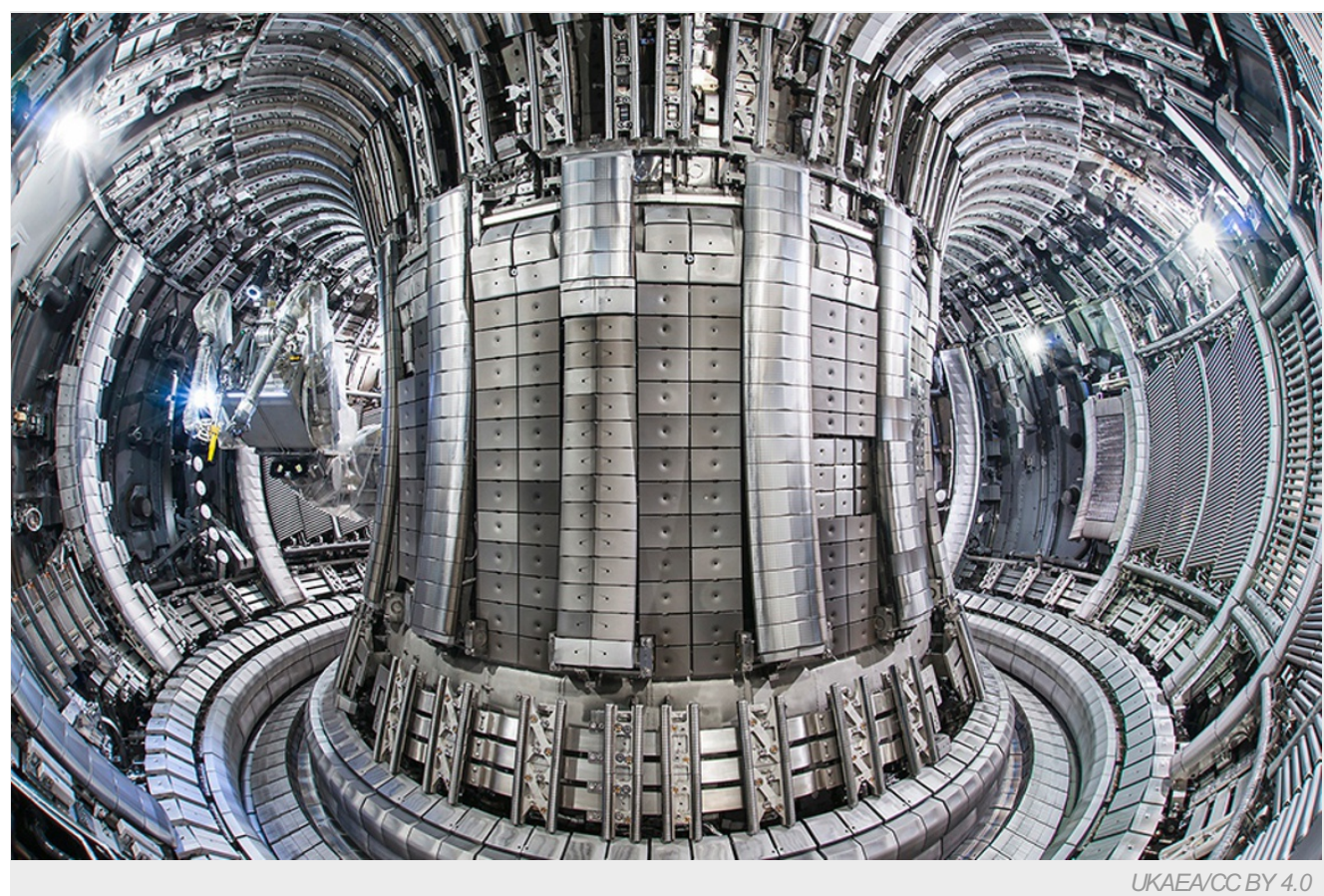

The UK's plan to leave Euratom has thrown into doubt the future of the Joint European Torus (JET), a nuclear-fusion facility in Culham, UK.

Scientists are shocked and angry at the UK government's sudden confirmation on 26 January that it wants to pull out of the European Atomic Energy Community, or Euratom, as part of its arrangements for Brexit.

Depending on whether and how the United Kingdom negotiates a way back in to the organization, the move could endanger British participation in the world's largest fusion experiment, the International Thermonuclear Experimental Reactor (ITER) in southern France. It could also curtail operations at the Joint European Torus (JET), a nuclear-fusion facility in Culham, UK. The facility is a half-sized version of ITER and acts as a test bed for it; it currently receives around $€ 56$ million ( $\$ 60$ million) annually from Euratom.

"It is simply bonkers to leave Euratom," says Steven Cowley, a theoretical physicist at the University of Oxford who until last year was director of the Culham Centre for Fusion Energy, which hosts JET.

"This has happened without discussion or analysis. It's left us in shock. Not the behaviour of a transparent government," tweeted Scientists4EU, a UK lobby group originally set up to campaign against the UK's exit from the European Union.

The Culham Centre's current chief executive, lan Chapman, told Nature that — after meeting with government officials - he is sure that the United Kingdom has no intention of drawing back from nuclear research and development or civil nuclear programmes. "There's no indication that this means we're stopping our nuclear programme, far from it," says Chapman, who is also chief executive of the UK Atomic Energy Authority.

The United Kingdom will have to change how it participates in these programmes, however. "There's still a commitment from the government to think about how we can put in place arrangements to continue running JET, and to continue participating in the ITER programme," Chapman says.

"The nuclear industry remains of key strategic importance to the UK and our withdrawal from the Euratom Treaty in no way diminishes our nuclear ambitions", a spokesperson from the Department for Business, Energy and Industrial Strategy says. 


\section{Quiet announcement}

Euratom predates the formation of the EU. But the two are legally entangled, and experts had predicted that Brexit would probably mean that the United Kingdom would also leave Euratom.

For months, it was unclear whether the UK government wanted to leave Euratom, or how a transition away from the agency would occur. (Nature received no response to questions on the issue).

But on 26 January, confirmation that it intended to leave Euratom appeared in notes appended to a short parliamentary bill. That legislation is meant to allow the UK prime minister to trigger Article 50, the formal notification of the United Kingdom's withdrawal from the EU.

Alexandrine Kántor, a senior electrical designer at the Culham Centre for Fusion Energy, said on Twitter that it was the first she'd heard of it. "Always nice to know you might lose your job via the newspapers, cause the gov' didn't think it necessary to tell your CEO," she wrote.

\section{Hazy consequences}

The consequences of pulling out of Euratom are uncertain, as are many of the implications of Brexit. Besides the uncertainty facing JET and ITER, some reports suggest that it could increase the costs of regulating existing nuclear facilities and delay the building of new power stations while the United Kingdom makes new arrangements.

The United Kingdom could become a Euratom 'third country', like the United States — which has a cooperation agreement that allows it to participate in some programmes. That status would not automatically make the United Kingdom a member of ITER, however. And although Euratom is technically able to fund projects in third countries, it would be unlikely to continue funding JET. The UK government has not said whether it would then pick up the bill for the facility.

Alternatively, the United Kingdom could become an 'associate country' — like Switzerland, which gained this status in 2014 and participates in ITER. Under this arrangement, Euratom would be more likely to continue funding JET.

JET's contract runs out in 2018 and negotiations over an extension to 2020 are ongoing. If the facility's funding is cut in 2019 , when the United Kingdom is currently scheduled to leave the EU, that could delay or prevent a fusion experiment at JET using the heavy hydrogen isotopes deuterium and tritium. This trial is intended as a dress rehearsal, to indicate whether ITER's magnetic-confinement technology will perform as hoped when it runs with this mix some time in the 2030 s.

The UK Nuclear Industry Association has called on the government to agree to transitional arrangements, which would see the United Kingdom remain part of Euratom until it had time to renegotiate international agreements that are currently all managed through the organisation.

The complex process of leaving Euratom should be done in a careful and deliberate manner, Chapman says, even if it takes longer than the two years prescribed for Brexit in Article 50. But the UK 'Brexit ministry' — the Department for Exiting the European Union — says that the two-year time limit applies to leaving Euratom as well.

Nature | doi:10.1038/nature.2017.21388 